\title{
DO MANUSCRITO AO IMPRESSO: A TRANSFORMAÇÁO DO PILOTO NUNO DA SILVA EM AUTOR
}

\section{FROM HANDWRITING TO PRINTING: THE TRANSFORMATION OF THE PILOT NUNO DA SILVA INTO AN AUTHOR}

Bianca Batista

Universidade Federal do Rio de Janeiro, UFRJ, Rio de Janeiro, RJ, Brasil

\begin{abstract}
Resumo: O objetivo deste artigo é analisar a história de publicação da narrativa do piloto português Nuno da Silva, assim como as estratégias de apropriação de narrativas ibéricas pelos editores e impressores ingleses. A tradução e publicação das narrativas dos pilotos portugueses e espanhóis nos livros impressos foram uma forma de romper a soberania dos reis ibéricos sobre as terras do Novo Mundo e promover a presença inglesa no Novo Mundo. Por conclusão, sugerimos que o livro impresso desafiou o monopólio das Coroas ibéricas e transformou os súditos ibéricos em autores de narrativas de viagem.
\end{abstract}

Palavras-chave: Nuno da Silva; expansão inglesa; livro impresso; autoria.

Abstract: This article's aim is to analyze the history of the publication of the deposition of the Portuguese pilot Nuno da Silva as well as the strategies of appropriation of Iberians' narratives by the English editors and printers. The translation and publication of Portuguese and Spanish pilots narratives in printed book was a way to break the Iberian kings sovereignty over the lands of the New World and to promote the English presence in the New World. As a conclusion, we suggest that the printed book challenged the Iberian monarchies monopoly and transformed the Iberian subjects into authors of travel narratives.

Keywords: Nuno da Silva; English expansion; printed book; authorship.

\section{Introduçáo}

A pergunta "o que é o autor?" norteia a explicação de Michel Foucault (2001) quanto aos aspectos sócio-históricos relacionados ao surgimento e ao desaparecimento da figura do autor. Essa mesma pergunta feita pelo filósofo francês há um século também norteia a nossa investigação sobre o 
relato do piloto português, Nuno da Silva, publicado no terceiro volume da coletânea de viagem do clérigo-editor inglês Richard Hakluyt, The Principal Navigations, Voyages, Traffiques and Discoveries of the English Nation (1600).

O interesse quanto a "quem é o autor" do relato provém das diferentes encarnaçôes materiais pelas quais o relato passou até chegar às mãos do clérigo-editor Richard Hakluyt e ser compilado como parte do corpus das viagens inglesas pela América do Norte e pela América do Sul. Os diferentes suportes do relato do piloto português (oral, manuscrito e impresso) e as traduçôes (espanhol, holandês e inglês) desencadearam novas atribuiçóes ao relato e a Nuno da Silva, visto que o texto náo é mais o mesmo quando circula por diferentes espaços editoriais.

A mudança de suporte material náo implica apenas outra forma de materialidade do texto, mas uma nova atribuição de sentido ao texto e aos sujeitos em virtude de os novos dispositivos atuarem na recepçáo e na compreensão do texto (CHARTIER, 1998). O sentido do texto também envolve os valores históricos e ideológicos do período em que foram escritos, traduzidos e impressos, evocando os regimes de verdade de uma dada sociedade. Donald Mckenzie (1999, p. 29) afirma que novos leitores constroem novos textos e os novos significados constroem novas formas. Pautado nisso, pode-se afirmar que Nuno da Silva é projetado como depoente e súdito da Coroa de Castela no suporte manuscrito enquanto no suporte impresso, Da Silva é projetado como autor de um relato e testemunha da viagem de circum-navegação de Francis Drake (1577-1580).

Os editores, tradutores e impressores atribuíram novas significações ao depoimento de Nuno da Silva, e, com isso, o público-alvo teve acesso a uma narrativa mediada por uma série de atores do cenário editorial e não ao texto na sua forma primeira - um depoimento oral. Os editores, tradutores e impressores, portanto, foram os "intermediários entre o autor e leitor" (CHARTIER, 2002, p. 37). Mckenzie (1999) afirma que o estudo da forma material do livro permite compreender as condiçôes em que os textos foram relidos, reeditados, reimpressos e republicados, e por isso entendemos que o suporte manuscrito atendia aos interesses das Coroas Católicas de manterem sigilo sobre as riquezas das suas colônias, enquanto o suporte impresso atendia aos anseios dos editores das naçóes concorrentes de divulgar as notícias sobre as terras recém-descobertas e romper o monopólio ibérico sobre o Atlântico e o Pacífico.

O depoimento de Nuno da Silva também aponta para uma prática comum no projeto expansionista inglês, a captura de pilotos e o saque às 
embarcações ibéricas. Mediante à captura de Nuno da Silva e de outros pilotos, Francis Drake conseguiu obter informaçôes náuticas e cartográficas para atravessar o Estreito de Magalhães, a costa do Pacífico, Oceania, e retornar à Inglaterra, realizando, assim, a missão que lhe fora atribuída pela rainha Elizabeth de realizar a primeira viagem de circum-navegação inglesa.

A partir da história de produção e publicação do depoimento do piloto português, investigaremos as estratégias discursivas que levaram a uma metamorfose de um depoente do tribunal em autor de um relato de viagem e a relevância da figura do autor para a autenticidade e a autoridade do relato de viagem na sociedade letrada.

\section{Nuno da Silva e a viagem de circum-navegaçáo de Francis Drake}

O piloto português Nuno da Silva foi capturado por Francis Drake próximo à Ilha de Cabo Verde, em 19 de janeiro de 1578, quando seguia viagem ao Brasil no navio português Maria (NUTTALL, 1914). O conhecimento marítimo do piloto auxiliaria Francis Drake a percorrer o Estreito de Magalháes, a costa da Nova Espanha e seguir seu percurso marítimo para cumprir a missão incumbida pela rainha Elizabeth I de "dar uma volta ao mundo" (NUTTALL, 1914, p. 296).

Ao longo da sua passagem pelo Atlântico e Pacífico, o corsário capturou pilotos e saqueou embarcaçóes e portos, desencadeando, com isso, um levantamento documental sobre os espólios de Drake. Todos aqueles que presenciaram as açôes do corsário foram intimados pelas autoridades locais a prestarem depoimentos que pudessem contabilizar as despesas ocasionadas por Drake e exigir o retorno das mercadorias roubadas e, caso necessário, fazer uso da força para que tais mercadorias fossem devolvidas, como afirma o embaixador espanhol Bernadino de Mendonza em suas correspondências com o rei Felipe II (JONES, 2000; SNYDER, 2006).

Max Weber (1999, p. 99) afirma que um dos processos envolvidos na formaçáo dos Estados foi o "monopólio da coação física legítima", isto é, o direito de um Estado de fazer uso da violência para assegurar seu monopólio dentro de "um determinado território geográfico [de] modo contínuo mediante a ameaça e a aplicação de coação física por parte do quadro administrativo". As correspondências entre o embaixador Bernardino de Mendonza, as autoridades coloniais e o rei Felipe II demonstram a projeção da "coação física" como uma medida para assegurar o direito de monopólio 
sobre as especiarias e o Novo Mundo.

Denver Brunsman (2019, p. 2), pautado nas teorias weberianas, afirma que a pirataria contribuiu para o desenvolvimento dos Estados modernos, pois o Estado "reivindica o monopólio do uso legítimo da força física dentro de um determinado território" (WEBER, 1946 apud BRUNSMAN, 2019, p. 2). O pesquisador compara o Atlântico a um território e a incursão de piratas em colônias e os saques aos navios a "uso da força", ilustrando, com isso, o direito que um Estado tem de utilizar diversas formas de coação e de violência física em um dado território que reclama para si em prol do seu crescimento, estabilidade e organicidade. Pautados nestes conceitos, pode-se considerar que a atuação de corsários ingleses, como Francis Drake, foi considerada pelo reino elizabetano como parte do direito de reivindicar, por meio de saques, roubos e sequestros, um direito de monopólio sobre as riquezas do Novo Mundo, uma vez que os ingleses não reconheciam a validade jurídica da divisão de territórios transoceânicos pela mediação de uma figura religiosa, o Papa.

Como a passagem de Drake pela Nova Espanha foi considerada pelos espanhóis uma afronta ao direito de monopólio, os depoimentos comporiam uma prova concreta dos danos causados e justificariam medidas violentas, a coação física legítima, contra corsários ingleses e até mesmo contra o reino elizabetano. Todavia, os depoimentos dos pilotos e dos tripulantes não forneceram apenas informaçóes sobre os saques de Francis Drake, mas sobre a relação amistosa entre Drake e Nuno da Silva. Tal relaçáo amistosa, como afirma Lisa Voigt (2009), problematizava as relaçóes de rivalidades religiosas, católicos versus protestantes, e de hierarquia, capturador versus cativo, o que identificava a dinâmica das açóes de pirataria como um cenário de disputa pela posse das terras ultramarinas.

Os depoentes, em sua maioria, afirmaram que Nuno da Silva e Francis Drake interagiam constantemente e conversavam em inglês ao longo da viagem, de forma que os cativos não entendiam a temática da conversa. Além disso, todos ressaltaram a participaçáo do piloto em cultos luteranos promovidos no navio (NUTTALL, 1914, p. 374). Em depoimento, Dom Luiz Velasco, dono de uma das embarcaçóes saqueadas, afirmou que o piloto português deveria ser intimado a depor o mais rápido possível, pois ele era o mais próximo de Drake e poderia fornecer mais informaçóes sobre todos os saques realizados (NUTTAL, 1914, p. 237) e os inquisidores do México, em correspondência com o alcaide de Guatulco (atualmente Huatulco), exigiram que o piloto fosse convocado a depor, pois a investigaçáo náo era 
apenas contra Drake, mas também contra Nuno da Silva pela prática de heresia (NUTTAL, 1914, p. 375).

Devido às denúncias de cumplicidade com o corsário, de participação em cultos protestantes e de ter sido o único piloto a permanecer mais tempo cativo, de 19 de janeiro de 1578 a 13 de abril de 1579 (NUTTALL, 1914, p. 296), Nuno da Silva foi convocado a prestar depoimento para o alcaide de Guatulco, Gaspar de Vargas, para o inquisidor do tribunal da inquisição, Bonilla, e para o vice-rei da Nova Espanha, Martin Enriquez.

O depoimento de Nuno da Silva e dos outros depoentes para as autoridades religiosas e políticas foi registrado em papel, manuscrito, a fim de que fosse enviado para as autoridades coloniais e ao rei Felipe II, de forma que pudesse ser formado um corpus documental contra o corsário e com isso exigir, em um primeiro momento, diplomaticamente, da rainha Elizabeth I, a restituição das mercadorias e das especiarias roubadas ao longo da viagem de circum-navegação como fizera o embaixador espanhol na Inglaterra, Bernadino de Mendonza, em sua carta à rainha em 14 de novembro de 1580 (HUME, 2013, p. 65).

Considerando que a "primeira coisa que Drake fazia ao capturar navios era saquear os mapas cartográficos, astrolábios e compassos" (NUTTALL, 1914, p. 121), o retorno de Francis Drake à Inglaterra envolvia muito mais do que a difusão das fragilidades dos portos; implicava, na verdade, o compartilhamento dos "segredos ibéricos" com outros ingleses, visto que o corsário aprendeu sobre as rotas marítimas com os pilotos capturados e roubou diversos documentos. Essa publicidade dos "segredos" não instigaria apenas a incursão de corsários pelo mar do Sul, mas a presença de estrangeiros pelas mais diversas partes do Novo Mundo, maximizando, assim, a "ameaça para segurança do reino" (HAKLUYT, 1600, p. 8)

O trânsito de cartas permitiria, dessa forma, aos governos das colônias adotarem medidas em conjunto para capturar o corsário. Como aponta Licenciado Palacios, a captura do corsário era algo urgente devido à "ameaça para a segurança do reino" que representava o retorno de Drake à Inglaterra, visto que o corsário poderia propagar informaçóes sobre os portos das colônias instigando, assim, outros ingleses a imitarem sua "audácia" em prol dos mesmos lucros, deixando o "mar do Sul repleto de corsários" (NUTTAL, 1914, p.122).

Devido a essas questôes, o depoimento oral de Nuno da Silva passa a ser incorporado no suporte manuscrito para atender às necessidades dos mediadores do texto, o alcaide, o inquisidor e o vice-rei. O contexto de 
produção do depoimento oral exigia que este fosse materializado no suporte manuscrito, pois o conteúdo náo poderia ficar restrito a efemeridade da oralidade, mas ser transportado para um suporte que lhe conferisse existência para além do seu momento de realizaçáo. O que antes era um depoimento sobre seu cativeiro perante autoridades políticas, alcaide e vicerei; autoridade religiosa, inquisidor; e um escriba passou a ser um documento administrativo contra Francis Drake.

\section{Materialidades do depoimento}

Em seus depoimentos, os pilotos Alonso Cochero e Nuno da Silva (NUTTALL, 1914, p. 296) afirmaram que Francis Drake mencionara que retornaria à Inglaterra pela China, e nesse percurso pelo continente asiático, por conseguinte, o corsário passaria pela Índia, que com a Unificaçáo Ibérica (1580), pertencia ao rei espanhol. De forma a evitar que Drake realizasse os mesmos saques na Índia e retornasse à Inglaterra com as mercadorias roubadas, as autoridades coloniais americanas enviaram às autoridades das Índias portuguesas informaçóes e depoimentos sobre as açóes de Drake para que o vice-rei soubesse acerca da periculosidade de Drake e tomasse medidas para evitar que o corsário concretizasse seu retorno à pátria.

A nova materialidade do depoimento permitiu que este pudesse ser copiado e circulasse por outras províncias, visto que "a escrita acumula, estoca, resiste ao tempo pelo estabelecimento de um espaço e multiplica sua produçáo pelo expansionismo da reprodução" (CERTEAU, 1994, p. 226). O suporte manuscrito conferiu um novo status e utilidade ao texto, apontando, assim, que essa tecnologia "permitiu aos [mediadores] e aos leitores reconstruir, reformular e disseminar os textos da forma que desejassem o que não era possível na fluidez imprecisa na oralidade" (McKenzie, 1999, p. 10).

Michel de Certeau (1994) afirma que a organicidade da sociedade escriturária europeia envolvia o uso da escrita, uma vez que as interaçóes econômicas, políticas, jurídicas e religiosas dos Estados não poderiam restringir-se ao momento da realização, mas perdurar no tempo e serem manuseados, copiados e replicados, permitindo, assim, "sobre um espaço próprio, a página, construir um texto que tem poder sobre a exterioridade da qual foi previamente isolado" (CERTEAU, 1994, p. 225).

Em virtude da hegemonia da escrita, os gêneros textuais escriturários 
possuíam mais prestígios do que os gêneros textuais orais, como bem exemplifica a análise de Certeau (1982) sobre o relato de Jean de Léry acerca dos autóctones da França Antártica. Léry afirmava que aquela sociedade ágrafa, limitada à oralidade, era inferior aos europeus, pois as histórias da formação do povo eram transmitidas apenas oralmente pelo gênero contação de história, sem a base manuscrita como fonte de autenticidade, estando as históricas, com isso, sujeitas à alteração a cada vez que eram contadas por diferentes pessoas. Outro indício de superioridade era a possibilidade de materializar a oralidade no papel e deslocá-la espacialmente de uma regiáo para outra, o que, segundo o huguenote, causara admiração nos tupinambás, visto que os franceses tinham a capacidade de reproduzirem os sons da língua dos autóctones ao lerem um papel e a capacidade de se comunicarem à distância por meio de cartas.

Esses valores vinculados à escrita permitem evocar a concepção de Pierre Bourdieu (1989, p. 14) sobre poder simbólico, isto é, um poder que é "dado pela enunciação de fazer ver e fazer crer, de confirmar ou de transformar a visão do mundo, e deste modo, a ação sobre o mundo". As instituiçôes sociais, jurídicas, literárias e econômicas atribuem valores e significados à escrita tornando-a em um poder simbólico que atua sobre os sujeitos e a coletividade e sobre a forma como estes interagem e concebem a si, o outro e o mundo. Esse poder exercido pela escrita, por sua vez, não envolve coação física, mas "a crença na legitimidade das palavras e daqueles que a pronunciam” (BOURDIEU, 1989, p. 14), o que implica que o poder está vinculado aos significados conferidos pelas instituições e à aceitação social desses significados, isto é, à cumplicidade entre os que exercem e aqueles que a ele se submetem, legitimando, com isso, seu poder.

Esse exercício de poder também envolve um sistema de controle de produçáo e circulação dos discursos, em especial no tocante às possessóes ultramarinas. Os diários de bordo, os relatos, os relatórios e os mapas produzidos pelos tripulantes ao longo da viagem não pertenciam a eles, mas a instituiçóes comerciais e reais que financiaram as expediçóes. Esse controle da produção textual começava no navio com o comandante (piloto maior) e o cosmógrafo confiscando os manuscritos e os mapas em posse dos pilotos, e prensando o selo real nos textos para assegurar o direito da Coroa sobre esses manuscritos (HAKLUYT, 1600, p. 885).

Considerando esses fatores, nota-se que as expediçóes marítimas envolviam dois tipos de mecanismos de controle, os gêneros textuais e os agentes do aparelho de vigilância. Os textos produzidos nessa situaçáo 
exigiam uma autoria, descrição minuciosa, precisão, dentre outros elementos que assegurassem a veracidade do texto, e, em decorrência disso, o sujeito não poderia escrever sobre qualquer coisa, mas obedecer às exigências escriturárias dos gêneros textuais e às exigências comerciais dos patrocinadores. Tais imposiçóes indicam que mesmo que a subjetividade perpasse os textos produzidos pelos sujeitos, estes obedecem a um conjunto de regras estabelecidas social e historicamente que integram o regime de verdade imposto em uma dada temporalidade. Isso implica que existe "um conjunto de procedimentos regulados para a produçáo, a lei, a repartição, a circulação e o funcionamento dos enunciados" (FOUCAULT, 2010, p. 11).

Em consonância a isso, os gêneros textuais estão sujeitos "aos mais variados tipos de controle social e até mesmo ao exercício de poder" (MARCUSHI, 2010, p. 7). Tal conceito implica que as regras das formações discursivas de um regime de verdade também estão vinculadas às instâncias políticas, jurídicas, científicas e literárias. Essas instâncias, por sua vez, possuem agentes de vigilância que delimitam os discursos que são ou não aceitos, àqueles que devem ser replicados, suprimidos, reprimidos e punidos.

Consequentemente, o gênero textual relato de viagem, materializado no suporte manuscrito, atendia aos interesses dos monarcas de possuir fisicamente as informaçóes sobre as rotas e as riquezas do Novo Mundo e, principalmente, de controlar a produção e a circulaçáo de informaçóes sobre as novas terras descobertas devido ao assédio dos reinos europeus sobre as Américas. Em virtude disso, havia um intenso controle sobre produção textual dos navegantes e pilotos ibéricos, permitindo, assim, entender que o gênero textual relato de viagem permitia "vigiar [os sujeitos] durante todo o tempo da atividade e submetê-los a uma perpétua pirâmide de olhares" (FOUCAULT, 2010, p. 106).

A partir disso, entendemos que o suporte manuscrito atendia aos anseios das nações ibéricas em manter as notícias sobre as terras recémdescobertas em sigilo, devido à possibilidade de maior controle sobre a produção e reproduçáo dos relatos, mapas e relatórios produzidos pelos seus súditos nas expediçôes marítimas. Os materiais textuais e cartográficos produzidos pertenciam juridicamente à Casa de Contratação e ao monarca, o que conferia a essas instâncias o direito de posse sobre os manuscritos originais e, consequentemente, um monopólio sobre as experiências dos súditos em territórios ultramarinos.

Esse controle sobre a produção e a reprodução dos discursos permitiu que documentos, depoimentos e relatos fossem copiados e enviados a outras 
áreas, sob a jurisdição de Castela, permitindo, com isso, uma mobilidade de conhecimentos úteis ao reino e a autoridades coloniais e religiosas. A materialização da experiência dos súditos em manuscrito permitiu que o vice-rei da Nova Espanha, Martin Enriquez, enviasse para o vice-rei das Índias Portuguesas, Dom Luiz de Athayde, o depoimento de Nuno da Silva para alertá-lo acerca do desejo de Drake de retornar à Inglaterra pela China (NUTTALL, 1914, p. 296).

Por mais que o destinatário da cópia do depoimento tenha sido o vice-rei das Índias portuguesas, outros sujeitos também tiveram acesso à carta, como Jan Huygen van Linschoten, secretário do arcebispo de Goa, João Vicente da Fonseca, e, provavelmente, outras autoridades e secretários que faziam parte do círculo político e religioso local. Durante os seis anos à frente desse cargo (1583-1589), na capital administrativa de Goa, Linschoten pôde observar a dinâmica comercial, política e religiosa da regiáo e ter acesso direto aos documentos administrativos, comerciais e inquisitoriais ibéricos. Em conjunto a esse corpus informacional, o secretário holandês também construiu conhecimentos sobre a regiáo, os nativos, os colonizadores, as viagens e as riquezas locais a partir da sua experiência na Índia, o que contribuiu para a abundante presença de ilustraçôes nas suas coletâneas.

Rosemary Arrojo (1992, p. 103) afirma que o tradutor tem papel "ativo de produtor de significados e de representante e intérprete do autor e dos textos que traduz", o que permite depreender que Linschoten produz novos significados aos documentos e às correspondências ibéricas traduzidas para o holandês, pois suas propostas interativas e ideológicas eram diferentes daquelas dos produtores desses textos. Além disso, o ato de traduzir não envolve uma reprodução estritamente fiel do texto original, "mas àquilo que consideramos ser o texto original, àquilo que consideramos constituí-lo, ou seja, à nossa interpretação do texto de partida, que será, como já sugerimos, sempre produto daquilo que somos, sentimos e pensamos" (ARROJO, 1992, p. 44).

Essas novas atribuiçôes aos textos traduzidos também atribuíram um novo status aos mesmos, que deixaram de ser uma propriedade das autoridades coloniais e passaram a ser propriedade do tradutor, conferindolhe dessa forma o direito de vendê-los a uma terceira pessoa, nesse caso, ao impressor Cornelius Claesz, o qual teve licença concedida pelos EstadosGerais da Holanda em 1594 para publicar os textos e as ilustraçóes de Linschoten sobre a dinâmica econômica, política e religiosa das colônias 
ibéricas e, principalmente, a descrição das viagens e das rotas marítimas.

Esse corpus textual sobre as Índias foi organizado em três coletâneas de viagem impressas em Amsterdam. O primeiro livro englobava as rotas das Índias Orientais, Pacífico e Ásia, Reys-gheschrift vande navigatien der Portugaloysers in Orienten ${ }^{I}$ (1595); o segundo apresentava as rotas das Índias Ocidentais, Pacífico, Atlântico e América, Itinerario: Voyage ofte schipvaert van Jan Huyghen van Linschoten naer Oost ofte Portugaels Indien, 1579-1592 (1595); e o terceiro destacou as rotas marítimas da África, Congo, Angola e América portuguesa, assim como a rota entre Portugal e Brasil, Beschryvinghe van de gantsche custe van Guinea, Manicongo, Angola ende tegen over de Cabo de S. Augustijn in Brasilien, de eyghenschappen des gheheelen Oceanische Zees ${ }^{3}$ (1597).

A impressão dos documentos ibéricos traduzidos para o holandês selava, definitivamente, a desarticulação do monopólio de Castela sobre os documentos produzidos pelos seus súditos nas suas possessóes, uma vez que as notícias sobre esses territórios deixavam de estar restritas a uma única cópia manuscrita e passavam a uma ampla reprodução em uma oficina tipográfica. Por meio da atuação do tradutor, os textos passaram a ser compreendidos em uma outra língua e, mediante o impressor, esses textos deixaram de ser restritos à forma manuscrita e passaram a existir na forma impressa.

A partir da publicação dos documentos na forma impressa, não é possível prever quantas pessoas acessaráo esses textos e nem os locais pelos quais os livros circularão. A reprodução de cópias impressas das coletâneas de Linschoten, em Amsterdam, visava um dado público leitor pelo editor e impressor. Todavia, a reproduçấo das coletâneas na oficina tipográfica viabilizou a circulação dessas obras para além de uma regiáo projetada, Londres. Em virtude da mobilidade espacial das coletâneas, os "segredos ibéricos" passaram a estar disponíveis materialmente em um novo local, mas inacessíveis àqueles que não dominavam a língua holandesa.

Mediante a atuação do impressor John Wolfe e do tradutor William Phillips, as coletâneas foram traduzidas para o inglês com o título John Huighen van Linschoten, His discours of voyages into ye Easte and West Indies (1598) e publicadas em um único volume. Na dedicatória ao patrono Julius

\footnotetext{
1"Relato de uma viagem pelas navegaçôes dos portugueses no Oriente".

2"Itinerário: navegação de Jan Huyghen van Linschoten às Índias Orientais portuguesas, 15791592”.

3"Descrição de toda a costa da Guiné, Manicongo e Angola e da travessia para o Cabo de Santo Agostinho no Brasil, com as características de todo o Oceano Atlântico”.
} 
Caesar, juiz da High Court Admiralty, Wolfe afirma que a tradução das coletâneas de Linschoten poderia contribuir para a expansão comercial inglesa em conjunto com a difusão do protestantismo e a civilidade aos nativos das terras ultramarinas, e que Richard Hakluyt o incentivou a traduzir essa obra, devido à riqueza textual e o seu potencial de promover o avanço da naçáo inglesa. Hakluyt inseriu algumas das narrativas ibéricas traduzidas dessa coletânea, em especial, o objeto de estudo, o depoimento de Nuno da Silva, em prol do seu projeto editorial de historicizar as viagens inglesas pelas Américas e a viagem de circum-navegação de Francis Drake.

A experiência ibérica transcendeu suas condiçóes de tempo e lugar, por meio do suporte impresso, e, com isso, desarticulou a amarra manuscrita que limitava a circulação do texto apenas na área de jurisdição ibérica. As notícias sobre as terras recém-descobertas, assim como os conhecimentos acerca das técnicas de navegação, deixavam de ser manuscritas e, consequentemente, de ser exclusividade da Casa de Contratação. O suporte impresso tocou a esfera de direito de posse, visto que as notícias sobre as novas terras passavam a ser de domínio público, violando, com isso, o monopólio da Coroa ibérica sobre os relatórios dos seus súditos. A proposta expansionista de Richard Hakluyt, por sua vez, se fundamentava justamente na violação territorial e informacional dos ibéricos. O clérigo-editor reportara ao patrono Robert Cecil, secretário de Estado, que a presença desses textos na coletânea de viagem representava o acesso aos segredos da Coroa espanhola (HAKLUYT, 1600 , p. 9)

O esforço de Hakluyt de ter em mãos os "segredos" ibéricos decorria do valor desses textos para o seu projeto editorial de encorajar viagens inglesas ao Novo Mundo. Esses relatos conferiam visibilidade aos leitores quanto à fertilidade e à potencialidade de riquezas que as terras do Novo Mundo poderiam a oferecer à nação, o que poderia instigar o leitor inglês a se lançar ao mar, a Coroa inglesa a conceder cartas de patente e a patrocinar expediçóes comerciais e colonizatórias no Novo Mundo, permitindo, assim, uma reconfiguração da presença inglesa no Novo Mundo.

A compilação de documentos e relatos ibéricos no livro impresso atendia perfeitamente às ambiçóes editoriais de Richard Hakluyt de promover a presença de colonos em empreitadas colonizatórias e exploratórias no Novo Mundo. Todorov corrobora essa assertiva ao abordar a viagem de Colombo como fruto da leitura do livro de viagem de Marco Polo: "ora, o relato de viagem não é, em si mesmo, o ponto de partida, e não somente o ponto de chegada, de uma nova viagem? O próprio Colombo 
não tinha partido porque tinha lido o relato de Marco Polo?” (TODOROV, 1999, p.15). A tradução e compilação das narrativas ibéricas pretendia o mesmo fim apontado por Todorov; uma leitura que instigasse os leitores a se lançarem em expediçōes marítimas.

Convencer os leitores ingleses a participarem de empreitadas marítimas era uma forma de estimular uma produção textual inglesa e uma "permanente documentação que permitiria a outros replicarem a viagem", indicando, com isso, que o livro impresso atendia a propostas de propagar informaçôes e "impelir uma escrita por novas mãos" (FULLER, 1995, p. 3 , tradução autor). A partir do momento que os leitores ingleses se lançassem em expediçóes marítimas, eles deixariam de ser meros leitores de empreitadas alheias e passariam a ser os agentes das viagens: "Richard Hakluyt nutriu e incentivou tanto a viagem inglesa quanto a escrita de viagens inglesas" (FULLER, 1995, p. 2).

O livro impresso, portanto, trazia às mãos dos leitores as rotas que os espanhóis e portugueses percorreram nas suas descobertas, promovendo o compartilhamento dos segredos da Coroa ibérica e encurtando a distância entre o leitor europeu e o piloto ibérico por proporcionar ao leigo o acesso às rotas marítimas e as informaçóes cartográficas, permitindo que qualquer leitor pudesse assumir um lugar no navio. A transformaçáo dos leitores ingleses em potenciais navegantes desencadearia mais viagens inglesas por diversas partes do globo e, consequentemente, a posse de novos territórios. Esses viajantes, por sua vez, retornariam à pátria com relatórios sobre as viagens que poderiam instruir e instigar outros navegantes ingleses a realizarem as mesmas empreitadas para "a honra da naçáo" e "terror e confusão dos inimigos” (HAKLUYT, 1600, p. 8, tradução do autor).

\section{Depoente e autor}

A comparação entre os títulos em espanhol (NUTTALL, 1914); holandês (LINSCHOTEN, 1586) e inglês (WOLFE, 1598; HAKLUYT, 1600) fornece indícios sobre a condução de uma leitura a favor das intenções dos editores. O título faz parte dos elementos paratextuais que configuram uma zona espacial, artefatos que contribuem para a significação do livro. A teoria de Gerárd Genette (2009) sobre os paratextos embasa a nossa análise sobre a função destes elementos para a construção social de sentido do texto.

Um dos aspectos elencados pelo teórico é o efeito do paratexto 
sobre o público leitor projetado e, também, sobre aqueles que "não o lêem necessariamente, ou não lêem [o livro] todo, mas participam da sua difusão e, consequentemente, da sua "recepção" (GENETTE, 2009, p. 71, grifo do autor). O título é um dos elementos paratextuais determinantes para a circulação e recepçáo de uma obra, ao conferir ao texto uma existência social e editorial decorrente de normas sociais vigentes na sociedade letrada e operaçóes escriturárias, em que o nome do autor exerce uma "função de classificação ao mesmo tempo que delimita, opóe e relaciona um certo número de textos entre si" (FOUCAULT, 2001, p. 273).

O leitor traz consigo um conjunto de expectativas referente ao gênero do texto que pode ser confirmada, reestruturada ou contradita, tanto no título quanto ao longo da leitura da narrativa. Nesse espaço textual, o editor utiliza de estratégias discursivas que propiciam uma leitura do texto orientada pelos seus valores ideológicos, por meio de estratégias discursivas e escolhas lexicais. O engajamento do editor em estruturar um título remete à atitude reflexiva do editor quanto ao tópico da narrativa e sua posição no contexto de comunicação em que os signos são valorados segundo tomadas de posição dos sujeitos em um dado momento interativo. E, nesse caso, a interação entre editor e leitor se faz por meio de artefatos paratextuais. Esse espaço textual é de responsabilidade do editor, que assume a função de "figurar a abertura de um texto para designá-lo, indicar seu conteúdo global e atrair o público visado" (GENETTE, 2009, p. 73), o que legitima seu posicionamento epistemológico e sua participação na construção de sentido sobre o tópico da narrativa.

Relacion del viage del corsario yngles que dio el piloto Nuńo de Silva ante su excelência del Virrey de Mexico a 20 de Mayo de 1579 y no la dio el su desmenuçada sino como se le iba perguntando respondia ${ }^{4}$

Een relaes ofte verhael van een Voyagie ofte Schip-vaert, ghedaen door den Piloot Nuno da Silva, voor zijn Excell. den Viçeroy van nieu Spaengien, den 20 Meye Anno 1579, binnen die Stadt van Mexico, van waert ghesonden is gheweest aenden Viçeroy van Portugaels Indien, waer inne verhaelt wordt die Coursen ende gheschiedenisse vande vaert van Françoys Draeck, die hem (belyder) ghenomen hadde by de Eylanden van Cabo Verde, ende alsoo met voerden, door die Straet van Magallanes, tot die Haven van Guatulco in nieu

${ }^{4}$ Disponível em: < http://memory.loc.gov/cgi-bin/ampage?collId=rbdk\&fileName=d001/ rbdkd001.db\&recNum=19\&itemLink=h?intldl/rbdkbib:@field(DOCID+@ $\underline{\text { lit(rbdk000001))>. Acesso } 30 \text { mar. } 2021 .}$ 
Spaengien daer hy hem weder liet varen ${ }^{5}($ LINSCHOTEN, 1939, p. 294).

The relation of a Voyage made by a Pilot called Nuno da Silva for the Viceroy of new Spaine, the 20. of May, in the yere of our Lord 1579. in the citie of Mexico, from whence it was sent to the Vice-roy of the Portugall Indies: wherein is set downe the course and actions passed in the Voyage of Sir Francis Drake that tooke the aforesayd Nuno da Silva at S. Iago one of the Islands of Cabo Verde, and caried him along with him through the Streights of Magellan, to the Haven of Guatulco in new Spaine, where he let him goe againe (HAKLUYT, 1600, p. 472)

The description of a voyage made by a pilot called Nuno da Silva for the viceroy of New Spaine, the 20 of May in the yeere of our lourde 1579 to the towne of Mexico, from whence it was sent to the viceroy of the Portugall Indies, wherein is set down the course and actions passed in the voyages of Sir Francis Drake that tooke the aforesaid Nuno da Silva by the Islands of Cabo Verde and carried him along with him thorough the Straightes of Magellanes to the Haven of Guatulco in New Spain, where he let him goe againe (WOLFE, 1589, p.416)

A posição de depoente do piloto português se faz presente no título do documento espanhol, visto que Nuno da Silva falava "dio" sobre a viagem de outrem, "corsário yngles", àquele considerado uma figura de extremo valor e respeito, "excelencia del virrey de Mexico". Da Silva não depôs por vontade própria, mas forçado no cenário ritualístico do tribunal, isto é, ele devia responder às perguntas feitas por um juiz ou autoridade do mesmo nível hierárquico, "no la dio el su desmenuçada sino como se le iba perguntando respondia". No título do texto em holandês, a posição de depoente é retomada apenas quando se refere ao local da sua captura, "die hem (belyder) ghenomen hadde by de Eylanden van Cabo Verde” ([Drake] pegou (o confessor) nas ilhas de Cabo Verde) enquanto na tradução inglesa

${ }^{5}$ Disponível em: < https://www.dbnl.org/tekst/lins001itin05 01/lins001itin05 010076. php>. "Um relatório da viagem de navio feita pelo piloto Nuno da Silva, para sua excelência o vice-rei da Nova Espanha, no dia 20 de maio de 1579, na Cidade de México, de onde foi enviado para o vice-rei de Portugal, onde se relata sobre as rotas e a história de navegaçáo de Francis Drake, que pegou o (confessor) nas ilhas de Cabo Verde, e, também, o carregou pelo Estreito de Magalhães até o porto de Guatulco, na Nova Espanha, onde ele foi permitido a continuar sua navegação" (tradução do autor).

${ }^{6}$ Disponível em: < http://memory.loc.gov/cgi-bin/ampage?collid=rbdk\&fileName=d0302// rbdkd0302. db \& recNum $=761$ \&itemLink $=r \% 3$ Fintldl $\% 2$ Frbdkbib $\% 3$ A $\% 40$ field\%28NUMBER\%2B\%40od1\%28rbdk\%2Bd0302\%29\%29\&linkText=0> Acesso em 30 mar. 2021

${ }^{7}$ Disponível em: < http://lcweb2.loc.gov/cgi-bin/ampage?collId=rbc3\&fileName=rbc0001_2007kis1964006000001 page.db\&recNum=537>. Acesso 30 mar. 2021 
a palavra "confessor" e a posição de depoente de Nuno da Silva é apagada.

A anulação dessa atmosfera inquisitorial no título impresso fez com que o depoimento de Nuno da Silva fosse projetado como um relato e não como um depoimento regulado pelo temor de represálias por parte das autoridades provinciais e religiosas. A mudança do tom coercivo do interrogatório fez com que Nuno da Silva deixasse de ser um depoente/ acusado de heresia e traição pelas autoridades e passasse a ser uma testemunha da viagem de circum-navegação de Francis Drake.

O título da narrativa em espanhol destaca "a viagem do corsário inglês" e na versão holandesa e inglesa "a viagem do piloto Nuno da Silva”. Essa diferença entre os agentes da viagem narrada póe em questão os diferentes tópicos que são destacados nos textos. No texto original, o que é posto em primeiro plano são as açôes de saque de Francis Drake, ao passo que no suporte impresso o destaque é o "relato da história de viagem" (Een relaes ofte verhael van een Voyagie); a "relação da viagem" (The relation of a Voyage) e "descriçẫo da viagem" (The description of a voyage) do piloto Nuno da Silva. Por ser autor de uma narrativa, seu discurso é "recebido de certa maneira e [recebe] certo status", isto é, ele "outorga certo estatuto ao discurso conferindo-lhe autenticidade (o discurso é real, verdadeiro), distinção (o discurso tem valor, é especial, importante) e permanência (o discurso conservar-se, fixa-se para a eternidade)" (FOUCAULT, 2001, p. 123).

Ainda quanto às mudanças do título, podemos trazer à tona o conceito de ordem de indexicalidade de Blommaert (2010). Segundo o pesquisador, quando os discursos transitam por diferentes espaços socioculturais, o que circula, de certa forma, é sua forma linguística e não seu valor. $\mathrm{O}$ signo passa a ser revestido de novos valores, e, com isso, "apontar" (indexicalizar) novos significados. A ressignificação do signo em novos espaços indica a estreita relação entre o signo linguístico e o contexto social. Podemos notar isso a partir das diferentes projeçóes dos sujeitos no título. No documento inquisitorial, Drake é indexicalizado como "corsário"; na tradução holandesa nenhuma titularidade é conferida a ele, enquanto na tradução inglesa, Drake é indexicalidado como "Sir". "Piloto" indexicaliza para as autoridades espanholas a profissão do réu enquanto para os editores, "piloto" indexicaliza um sujeito de notório conhecimento náutico no cenário das grandes navegaçóes.

Considerando que o corso fazia parte do projeto expansionista inglês (JOWITT, 2010), entendemos que os editores ingleses interpretam os 
saques de Drake como elemento integrante das viagens. Hakluyt corrobora esta assertiva ao afirmar ao patrono do terceiro volume da coletânea, Robert Cecil, secretário de Estado, que o saque às embarcaçóes e aos portos ibéricos viabilizavam o acesso aos segredos ibéricos, "pela tomada de seus navios e os saques de suas vilas e cidades, a maioria dos seus segredos sobre as Índias Ocidentais e de todas as partes caíram nas mãos do nosso povo (os quais em tempos remotos eram, em sua maioria, desconhecidos para nós" (HAKLUYT, 1600, p. 8, tradução do autor).

Jowitt (2010) afirma que Francis Drake recebeu o título Sir da rainha Elizabeth I, após retornar da sua viagem de circum-navegação com a embarcação Golden Hind repleta de mercadorias roubadas. O título conferido a Drake em virtude das açóes de corso realizadas ao longo da sua viagem de circum-navegação soava como uma contradição, visto que as açôes de pirataria eram valoradas negativamente na sociedade inglesa e alvo de puniçôes segundo as leis internas denominadas Offences at sea act (1536) e Proclamation against the maintenance of pirates (1569).

As diferentes indexicalizaçóes também se fazem presentes em relação àquele a quem Nuno da Silva dirige sua narrativa. O vice-rei era um dos representantes da Coroa espanhola na América e figura de extremo destaque social, e, por isso, digno do pronome de tratamento "excelência". Esta titularidade da autoridade real se faz presente nos títulos em espanhol e holandês, "su excelência" e "zijn Excell". Em contrapartida, os ingleses não reconhecem o direito de posse ibérico sobre o Novo Mundo e nem as hierarquias das autoridades coloniais e reais, o que se fez presente no campo paratextual com o apagamento do pronome "excelência" no título. Percebemos, portanto, que um texto não é o mesmo quando transita por diferentes espaços e que as estruturas socioideológicas locais orientam a ressignificação dos sujeitos e da temática reportada no título.

Vale lembrar que o gênero relato de viagem evoca na mente do leitor um repertório de características desse gênero, e uma destas características é o nome do autor. A "autenticação de uma narrativa reclama o emprego de um nome próprio" (CHARTIER, 2014, p. 52) e o nome do autor, de certa forma, faz parte de "marcas discursivas que diferenciavam os relatos de viagem da narrativa ficcional” (COSTA LIMA, 2009, p. 186). Como o nome do autor permite saber que "isso foi escrito por tal pessoa"” ou "tal pessoa é o autor disso" (FOUCAULT, 2001), o seu discurso é "passível de ser constatado", o que lhe confere um caráter verídico e factual.

O clérigo-editor assumiu o compromisso de associar "cada viagem 
ao autor, que em pessoa, realizou e escreveu sobre a mesma" (HAKLUYT, 1598 , p. 5, tradução do autor). O relato de Nuno da Silva se configuraria, portanto, como uma contradição às palavras de Hakluyt, visto que àquele a quem é atribuída à autoria (Nuno da Silva) não é quem escrevera o texto (escrivão). Se levarmos em consideração o conceito de Foucault (2001) de que os discursos literários não podiam mais ser aceitos senão quando providos da função-autor, entendemos que os relatos de viagem também não poderiam ser socialmente aceitos sem um nome ao qual pudesse ser atribuído o que foi escrito. A funçáo-autor, portanto, é "marcada pelo nome próprio, que [classifica] os discursos e os [atribui] a uma identidade única" (CHARTIER, 2014, p. 6).

A função-autor é uma exigência discursiva de determinados textos na sociedade letrada por determinar "o modo de existência, de circulação e de funcionamento de certos discursos no interior de uma sociedade" (FOUCAULT, 2001, p. 74) e "por [certificar] e [atribuir] verdade a alguns discursos e não a outros" (CHARTIER, 2014, p.40). O autor (auctor) era o elemento de autoridade (auctoritas) e autenticidade (autenticus) do texto e, por isso, suas palavras deveriam ser reproduzidas fielmente pelos editores para náo ferir a autenticidade do mundo observado, "o mundo dos viajantes observados por seus próprios olhos está aqui, na maior parte, em suas próprias palavras transcritas ou traduzidas" (PURCHAS, 1906, p. 53, tradução do autor).

Considerando o contexto de produçáo do depoimento de Nuno da Silva, ele não é quem escreve, mas é a origem do texto e o foco da sua coerência, de forma que sua presença na viagem de Drake como prisioneiro, o tornava testemunha dessa açáo e, portanto, um "autor de autoridade"; "eu encontrei qualquer autor de autoridade pertencente ao meu argumento, tanto estrangeiro quanto nativo, e registrei palavra por palavra com seu nome particular" (HAKLUYT, 1600, p. 9, tradução do autor). Purchas reforça tal assertiva ao afirmar que as coletâneas do seu antecessor, Hakluyt, e as suas apresentavam narrativas traduzidas e transcritas que obedeciam fielmente ao mundo observado pelos olhos dos viajantes (PURCHAS, 1906, p.53). Dessa forma, o testemunho de Nuno da Silva retirava seu nome do anonimato, e, com isso, ele deixava de ser um mero nome próprio e passava a ser o nome de um autor de viagem.

\section{Consideraçóes Finais}


A comparação dos títulos da narrativa do piloto em espanhol, holandês e inglês fornece pistas quanto à valoração das ações de Drake pela ótica de diferentes atores envolvidos na datação e tradução do depoimento e, principalmente, quanto à configuraçáo deste espaço paratextual como uma arena, onde são mobilizadas formas simbólicas que sustentam positivamente e negativamente Francis Drake e Nuno da Silva e a escolha do que mereça ser posto em destaque no primeiro contato do leitor com o texto.

A história de produção e publicação deste texto indica que "a reconstrução histórica [do texto] permite entender que a [sua] significação depende das formas e das circunstâncias por meio das quais os textos são recebidos e apropriados pelos leitores" (CHARTIER; CAVALLO, 1998, p. 6). Os mediadores interpretaram o depoimento à luz do contexto social, histórico e ideológico das suas localidades e, com isso, atribuíram novas significações ao texto, "um texto se reveste de uma nova significação e de um estatuto inédito quando mudam os suportes que o propóem à leitura" (CHARTIER; CAVALLO, 1998, p. 6).

Em conjunto a isso, a disposição de um texto em diferentes suportes convida a pensar que "a encarnação do texto em uma materialidade específica carrega diferentes interpretaçōes, compreensóes para diferentes públicos" (CHARTIER, 1998, p. 18). Os dispositivos materiais pelos quais o texto se apresenta a um dado público leitor contêm indícios dos diferentes contextos socioculturais e ideológicos que o condicionam. A "viagem" do texto de uma localidade a outra envolve um encontro com diferentes repertórios culturais e interlocutores/leitores. A circulação do texto em outras localidades também envolve novas formas de valoração e mecanismos de ressignificação do texto por parte dos sujeitos que com ele interagem.

Partindo do conceito de Norman Fairclough (2001, p. 91) de que o discurso é um modo de ação, uma forma como as pessoas podem agir sobre o mundo e, especialmente, sobre os outros, podemos propor que o cenário político-editorial inglês visava aos seguintes leitores alvo: os patronos, os comerciantes, a Coroa e um público inglês geral de leitores. Os comerciantes poderiam ser futuros patrocinadores, a Coroa tinha autoridade de conceder cartas de patente e o leitor comum poderia vir a se tornar um navegante inglês e, consequentemente, um autor de relatos de viagens.

No tocante à materialidade do texto, pode-se recorrer aos conceitos de David Armitage (2000) sobre a era elizabetana. Segundo o pesquisador, o corso nas Américas visava a uma promoção do mare liberum (mar aberto), enquanto o monopólio ibérico sobre o continente visava ao mare clausum 
(mar fechado), e essa defesa de mar aberto e fechado pelas Coroas não envolvia apenas a presença nos mares, mas a materialidade de relatos e documentos. A "liberdade dos mares", defendida pelos ingleses, envolveu tanto o corso quanto tecnologia da imprensa. Mediante tal prática, os corsários conseguiram circular em territórios que pertenciam às Coroas católicas forçando, assim, uma abertura desses "mares" à Inglaterra. O livro impresso, por sua vez, promoveu a livre circulação dos segredos ibéricos para novos espaços, desarticulando, assim, o direito exclusivo dos ibéricos sobre o discurso dos seus súditos. Pautado na semelhança gráfica entre as palavras "livro" e "liberdade" em latim, "liber (livro) / liber (liberdade)" (CANFORA, 2003, p. 73), acreditamos que a inclusão de relatos ibéricos em coletâneas impressas inglesas promovia a liberdade desses textos do domínio de Castela.

A incorporação de manuscritos ibéricos nas coletâneas impressas também desencadeou transformaçóes nos textos e sujeitos. Os manuscritos perderam seu caráter documental no suporte impresso e passaram a vigorar como narrativas de viagem. Esse gênero literário, por sua vez, exigia a presença de um nome ao qual pudesse ser atribuída a viagem narrada. A autoria determinava o "modo de existência, circulação e funcionamento de certos discursos no interior de uma sociedade" (FOUCAULT, 2001, p.74) e uma relaçáo de homogeneidade, filiação e autenticação com os outros textos. Pautado nessa premissa, a autoria conferiu credibilidade/veracidade à narrativa de Nuno da Silva possibilitando, assim, que a narrativa fosse incorporada em conjunto com outras sobre o Brasil, Cabo Verde e Rio da Prata na coletânea de John Wolfe, John Huighen van Linschoten, His discours of voyages into ye Easte and West Indies (1598) e junto àquelas referentes à viagem de circum-navegação de Francis Drake na coletânea de Richard Hakluyt, The Principal Navigations (1600).

A transformação do piloto em autor permitiu perceber que o caráter transformador do livro também se aplicava ao seu público leitor. $\mathrm{Na}$ primeira edição da coletânea, The Principal Navigations (1598), Hakluyt deixa explícito ao patrono o poder transformador do livro. Segundo o clérigo-editor, os livros de cosmografia instruíram sua ignorância sobre as novas terras até então descobertas, ao mesmo tempo que o instigaram a ler os mais diversos livros sobre viagens e descobertas realizadas pelas naçóes europeias. Esse artefato o instruíra e instigara à leitura de mais livros sobre esta temática e, por isso, Hakluyt recorrera ao suporte impresso para "educar mentes para corajosas e elevadas empreitadas" e, com isso, convencer os ingleses a "levantarem as âncoras" em prol de viagens táo prósperas quanto 
a dos ibéricos (HAKLUYT, 1598, p.12).

O livro impresso, portanto, instruía e instigava novas viagens ao Novo Mundo e a capacidade desse artefato de desarticular o monopólio informacional dos ibéricos, transformar os sujeitos em autores e os leitores em uma nova geraçáo de navegantes nos permite entender o motivo pelo qual Samuel Purchas (1906, p.173) considerava o impresso e a navegação as maiores atribuições da indústria humana.

\section{Referências}

ARMITAGE, David The ideological origins of the British Empire. Cambridge: Cambridge University Press, 2000.

ARROJO, Rosemary. Compreender x interpretar e a questão da tradução. In: ARROJO, Rosemary (Org.). O signo desconstruído: implicaçôes para a tradução, a leitura e o ensino. Campinas: Pontes, 1992

BLOMMAERT, Jan. A messy new market place. The Sociolinguistics of globalization. Cambridge: Cambridge University Press, 2010, p. 28-62.

BOURDIEU, Pierre. O poder simbólico. Lisboa: Difel, 1989.

BRUNSMAN, Denver. Piratas vs. Bandos de Recrutamento: A batalha pelo Atlântico. Tradução de Marcos Sonilla Pinheiro. História, Sáo Paulo, v.38, $\mathrm{n}^{\circ}$ 1, p. 1-16, jan 2019. Disponível em: < https://www.scielo.br/pdf/his/ v38/pt 1980-4369-his-38-e2019004.pdf >. Acesso em 30 mar.2020.

CANFORA, Luciano. Livro e liberdade. Tradução de Antonio de Pádua Danesi. São Paulo: Ateliê Editorial, 2003

CERTEAU, Michel de. A escrita da história. Tradução de Maria de Lourdes Menezes. Rio 99 de Janeiro: Forense-Universitária, 1982.

. A invençáo do cotidiano. Rio de Janeiro: Vozes, 1994.

CHARTIER, Roger.A ordem dos livros. Leitores, autores e bibliotecas da Europa entre os séculos XIV e XVIII. Tradução de Mary Del Priorre. Brasília: Universidade de Brasília, 1998.

. Do palco à página. Publicar teatro e ler romances na época moderna (séculos XVI-XVIII). Tradução de Bruno Feitler. Rio de Janeiro: Casa da Palavra, 2002.

Os desafios da escrita. Tradução de Fluvia Moretto, São Paulo:

UNESP, 2002. 
O que é um autor? Revisão de uma genealogia. Traduçáo de Luzmara Curcino e Carlos Bezerra. São Carlos: EDUFSCAR, 2014.

. Práticas de leitura. Tradução de Crsitiane Nascimento. São Paulo: Estação Liberdade, 1996.

; CAVALLO, Guglielmo. História da leitura no mundo ocidental. Tradução de Fulvia Moretto (inglês), Guacira Marcondes Machado (francês) e José Antônio de Macedo Soares (inglês). São Paulo: Ática, 1998.

COSTA LIMA, Luiz. O controle do imaginário \& a afirmaçáo do romance: Dom Quixote, as relaçóes perigosas, Moll Flanders, Tristram Shandy. Sáo Paulo: Companhia das Letras, 2009.

FAIRCLOUGH, Norman. Discurso e mudança social. Tradução de Izabel Magalhães. Brasília: Editora Universidade de Brasília, 2001

FOUCAULT, Michel. Microfísica do poder. Rio de Janeiro: Ediçôes Graal, 2010.

O que é um Autor? In: Estética: Literatura e Pintura, Música e Cinema. Rio de Janeiro: Forense Universitária, 2001. p. 264-298. (Col. Ditos e Escritos III).

FULLER, C. Mary. Voyages in print: English travel to America 15761624. Cambridge: Cambridge University Press, 1995.

GENETTE, Gérard. Paratextos editoriais. Tradução de Álvaro Faleiros. São Paulo: Ateliê Editorial, 2009.

HAKLUYT, Richard. The Principal Navigations, Voyages, Traffiques \& Discoveries of the English Nation [1598-1600]. Disponível em: <http:// memory.loc.gov/cgi-bin/query/h?intldl/rbdkbib:@field(NUMBER+@ band(rbdk+d0301))>. Acesso em: 30 mar. 2021.

HUME, Martin. Calendar of Letters and State Papers Relating to English Affairs. Preserved Principally in the Archives of Simancas. Volume 3. Cambridge: Cambridge University Press, 2013.

JONES, Dodie. Royal protectors, explorers, and thieves: pirates of the Elizabethan cold war, 1558-1685. 2000. 64p. Trabalho de conclusão de curso (Monografia em História) - Departamento de História, Universidade de Richmond, Virgínia. 2000.

JOWITT, Claire. The Culture of Piracy, 1580-1630: English Literature and Seaborne Crime. Farnham: Ashgate Press, 2010.

LINSCHOTEN, Jan Huygen. Iohn Huighen van Linschoten his Discourse of voyages into ye East $\&$ West Indies: divided into four 
books. Edited by John Wolfe translated by William Phillip. London: 1598. Disponível em: < https://www.loc.gov/resource/rbc0001.2007kis19640060 00001/?sp=10>. Acesso 30 mar. 2021.

. Itinerario: voyage ofte schipvaert van Jan Huygen van Lischoten naer Oost ofte Portugaels Indien, 1579-1592. Disponível em: https://www. dbnl.org/tekst/lins001itin05 01/lins001itin05 01 0076.php > Acesso 30 mar. 2021.

MARCUSCHI, Luiz. O Papel da Atividade Discursiva no Exercício do Controle Social. Cadernos de Linguagem e Sociedade, v. 7, no5 p. 07-33, 2010. Disponível em:

$<$ https://periodicos.unb.br/index.php/les/article/view/9697/8564>. Acesso em: 30 mar. 2021.

McKENZIE, D.F. Bibliography and the Sociology of the Texts. Cambridge: Cambridge University Press, 1999

NUTTALL, Zelia. New Light on Drake. A collection of documents relating to his voyage of circumnavigation 15770-1580. London: Hakluyt Society, 1914.

PURCHAS, Samuel. Hakluytus posthumus, or Pvrchas his Pilgrimes. Glasgow: James MacLehose and Sons Publishers to the University, 1906.

SNYDER, Amanda. The politics of piracy. Pirates, privateers and the government of Elizabeth I. 2006.117p. Dissertação (Mestrado em História) - Departamento de História, Universidade da Carolina do Norte, Wilmington.2006.

TODOROV, Tzvetan. A conquista da América: a questão do outro. Tradução de Beatriz Perrone Moisés, 2a ed. São Paulo: Martins Fontes, 1999.

Writing Captivity in the Early Modern Atlantic. Carolina do Norte: University of North Carolina Press, 2009.

WEBER, Max. Economia e sociedade: fundamentos da sociologia compreensiva. Brasília: UnB. 2v. 1999. 